\title{
Re-evaluation of Large Dams in Van Inner Basin, Turkey
}

\author{
Hasan Tosun ${ }^{1}$ \\ ${ }^{1}$ Eskisehir Osmangazi University, Civil Engineering Department \\ Odunpazari, Eskisehir, Turkey \\ htosun@ogu.edu.tr
}

\begin{abstract}
In Turkey, there are twenty-five river basins. One of them is Van Inner Basin, which is located near Iran border, having 1.79 million hectares of surface area in East Turkey. This basin includes more than 40 dams. Most of them are small embankment dams. Major earthquakes with the potential of threatening life and property occur frequently in the basin. A national safety program was commenced to re-evaluate large dams of the basin. This paper summarizes the methods considered for earthquake safety evaluation and introduces the results of the study, which was performed for six large dams, namely Kockopru, Morgedik, Patnos, Sarımehmet, Sihke and Zernek dams in Van Inner basin. The seismic hazard analyses have indicated that peak ground acceleration changes within a wide range for dam sites of this area. The total risk analyses depending on the seismic hazard rating of dam site and risk rating of the structure have concluded that most of these large dams have high-risk class and can need design and construction measures to tolerate requirements resulting from updated seismic codes.
\end{abstract}

Keywords: Embankment dam, Seismic hazard, Total risk.

\section{Introduction}

There are so many factors acting on total risk for dam structures. Two of them, namely seismic hazard rating of dam site and risk rating of the dam and appurtenant structures, most important factors for total risk of dams. The seismic hazard of a dam site is based on the peak ground acceleration. The risk rating of the dam is defined on the basis of capacity of the reservoir, height of the dam, evacuation requirements and potential downstream damages. In general, the seismic and risk ratings are evaluated separately [1]. These two factors were combined to define the total risk factor for dam structure [2]. Recently, the guidelines for selecting seismic parameters for large dams have been published by ICOLD [3].

Total number of large dams constructed throughout all country is more than 1250 in Turkey. Most dams are of the embankment type. However, number of concrete dams and rolled compacted concrete dams increases recently. Most of the dam engineers in Turkey believe the fact that embankment dams, which are well compacted according to the specification, are suitable type for regions having high seismic activity. However, authors think that strong ground shaking can result in the instability of the embankment and loss of strength at the foundations, especially for dams which are under near source effect.

Van Inner Basin is located near Iran border, having 1.79 million hectares of surface area in East Turkey and includes more than 40 dams. Most of them are small embankment dams. Major earthquakes with the potential of threatening life and property occur frequently in the basin. The significant earthquake with a magnitude $\left(\mathrm{M}_{\mathrm{w}}\right)$ of 7.2 took place on October 23, 2011 near Lake Van [4]. The epicenter is about $30 \mathrm{~km}$ to the north of Van city center. Because of its shallow focal depth of about $10 \mathrm{~km}$ the ground shaking in the epicenteral region was very severe. The national seismo-tectonic map was updated as including new structural features in 2013. The investigation area is structurally cut by secondary faults, which are resulted by two main-faulting system throughout country. Another earthquake with magnitude of Mw 7.3 (Halabja Earthquake), which took place at Iran-Iraq border in 2017, was close to the investigation area [5].Therefore, earthquake safety is an important concept for dams and their appurtenant structures. This paper deals with an evaluation of seismic hazard and total risk of the large dams, which have a hydraulic height between $11.2 \mathrm{~m}$ and $62.4 \mathrm{~m}$, in the Van Inner Basin (Fig. 1). In the basin, more than ten large dams have been designed to exploit energy and irrigational potential of the basin. In this study six of them, which are under operation now, are considered in this study. Their physical properties are summarized in Table 1. 


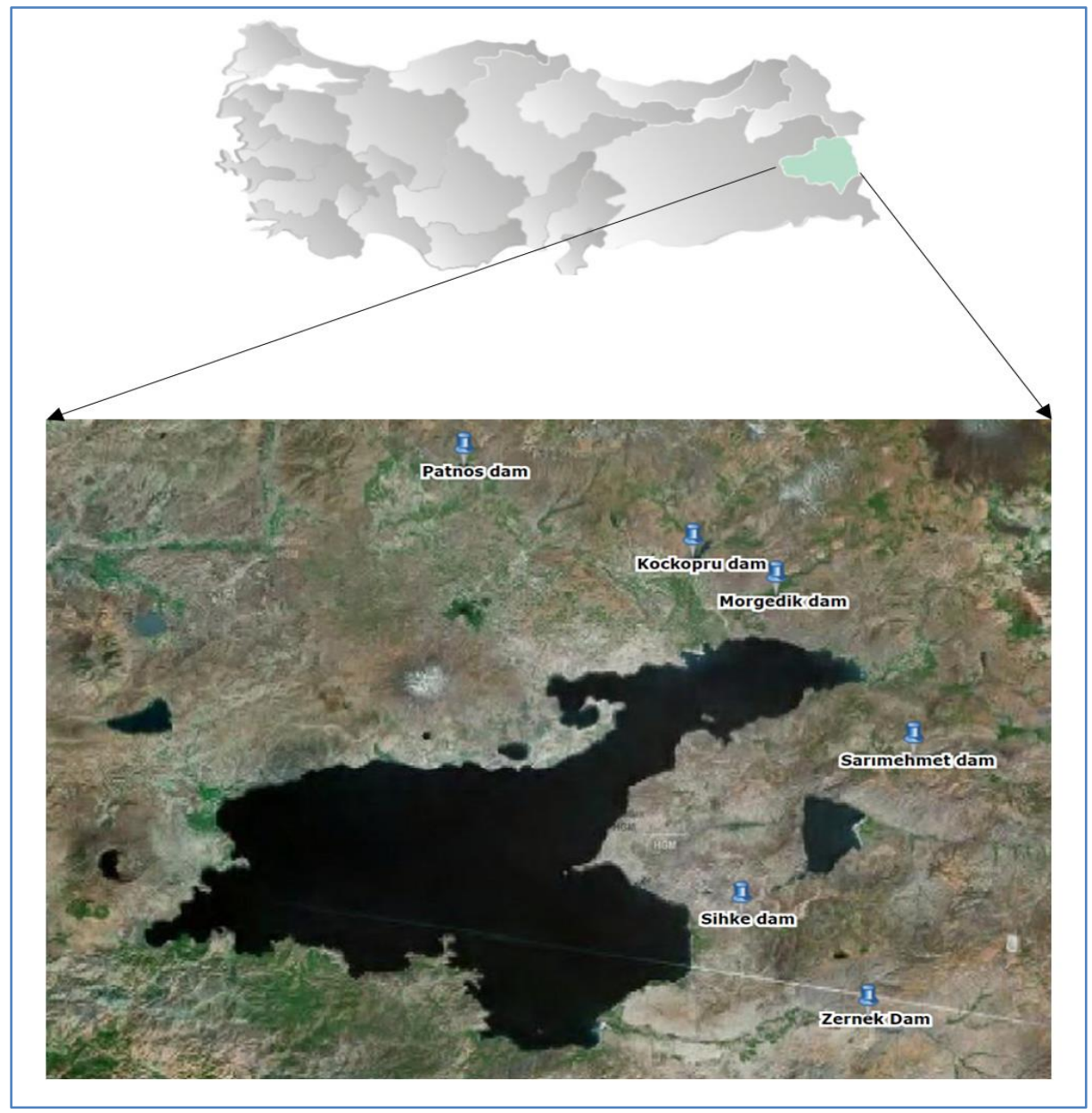

Fig. 1: Location of dams considered for this study [6].

Table 1: Physical properties of large dams considered for this study.

\begin{tabular}{|l|l|l|l|l|l|l|l|}
\hline N0 & Dam & $\begin{array}{l}\text { Aim } \\
(*)\end{array}$ & $\begin{array}{l}\text { Height } \\
\text { from river } \\
\text { bed }(\mathrm{m})\end{array}$ & $\begin{array}{l}\text { Completed } \\
\text { Year }\end{array}$ & $\begin{array}{l}\text { Type } \\
(* *)\end{array}$ & $\begin{array}{l}\text { Volume of } \\
\text { embankment } \\
\left(\mathrm{hm}^{3}\right)\end{array}$ & $\begin{array}{l}\text { Volume of } \\
\text { reservoir } \\
\left(\mathrm{hm}^{3}\right)\end{array}$ \\
\hline 1 & Kockopru & I+E+F & 51.0 & 1992 & EF & 2.0 & 86.5 \\
\hline 2 & Morgedik & I & 55.0 & 2014 & RF & 0.7 & 102.5 \\
\hline 3 & Patnos & I & 32.0 & 1991 & EF & 1.3 & 33.4 \\
\hline 4 & Sarmehmet & I & 47.0 & 1991 & RF & 1.2 & 133.3 \\
\hline 5 & Sihke & I+D & 11.2 & 1957 & EF & 0.4 & 9.2 \\
\hline 6 & Zernek & I+E+F & 62.4 & 1988 & RF & 2.1 & 105.8 \\
\hline
\end{tabular}

* E: Energy I: Irrigation FC: Flood control D: Domestic Water

** RF: Rockfill EF: Earthfill 


\section{Methods of Analyses}

The deterministic and probabilistic seismic hazard analyses are generally used for the study of seismic activity for dam sites. Krinitzsky [7] states that deterministic seismic hazard analysis considers geology and seismic history to identify earthquake sources and to interpret the strongest earthquake with regardless of time. The probabilistic seismic hazard analysis is widely used and considers uncertainties in size, location and recurrence rate of earthquakes. Kramer [8] states that the probabilistic seismic hazard analysis provides a framework in which uncertainties can be identified and combined in a rational manner to provide a more complete picture of the seismic hazard.

For the dams in Van Inner Basin eight separate predictive relationships for horizontal peak ground acceleration were considered [9]-[16]. However, some data have been excluded for the study because of giving extreme values. For each dam site all possible seismic sources were identified and their potential was evaluated in detail, as based on the guidelines [17] and the unified seismic hazard modelling for Mediterranean region introduced by Jiminez al [18]. As a result of an extensive survey and a search of available literature, several sources have been identified to help analyzing the seismic hazard of dams in Turkey. The data instrumentally recorded earthquakes for Turkey and vicinity collected by the National Disaster Organization were considered as a basis for the seismic hazard analyses. The earthquakes that occurred within the last 100 years were used for estimating seismic parameters. Throughout the study, seismic zones and earthquakes within the area having a radius of $100 \mathrm{~km}$ around the dam site were considered.

International Commission on Large Dams (ICOLD) states that the Maximum Credible Earthquake (MCE) is the largest reasonably conceivable earthquake magnitude that is considered possible along a recognized fault or within a geographically defined tectonic province [3]. According to this specification, the Safety Evaluation Earthquake (SEE) is defined as the maximum level of ground motion for which the dam should be designed or analyzed. For the dams with high total risk, it is recommended that the SEE should be characterized by a level of motion equal to that expected at the dam site from the occurrence of a deterministically-evaluated maximum credible earthquake or of the probabilisticallyevaluated earthquake ground motion with a very long return period.

Earthquake definitions given by FEMA [19] were considered for seismic hazard analyses in this study. The Operating Basis Earthquake (OBE), which was defined by means of the probabilistic methods mentioned above, is the earthquake that produces the ground motions at the site that can reasonably be expected to occur within the service life of the project. MDE is normally characterized by a level of motion equal to that expected at the dam site from the occurrence of deterministically evaluated MCE. Safety Evaluation Earthquake (SEE) is the level of shaking for which damage can be accepted but for which there should be no uncontrolled release of water from the reservoir. Most of large dams in Turkey were analyzed by using these definitions in past [20]- [36].

Throughout this study, two methods have been considered to determine total risk of the dams. In DSI guidelines, total risk factor depends to reservoir capacity, height, evacuation requirement and potential hazard [37]. The Bureau method, which considers dam type, age, size, downstream damage potential and evacuation requirements, was utilized to realize the risk analyses of the basin. It recommends four separate risk classes ranging from I (low risk) to IV (extreme risk) as based on the Total Risk Factor (TRF).

\section{Seismic Hazard Analyses}

For the dam sites in the Van Inner Basin, a detailed study was performed to identify all possible seismic sources, as based on the seismic zonation map of Turkey, given in Fig. 2. The map for general use, prepared by the National Disaster Organization and other Institutes, was modified by the author and co-workers to use for dam projects. Local geological features and seismic history were used to quantify the rate of seismic activity in the basin. As a result of detailed evaluation, total area covering all basins was separated into three seismic zones. 


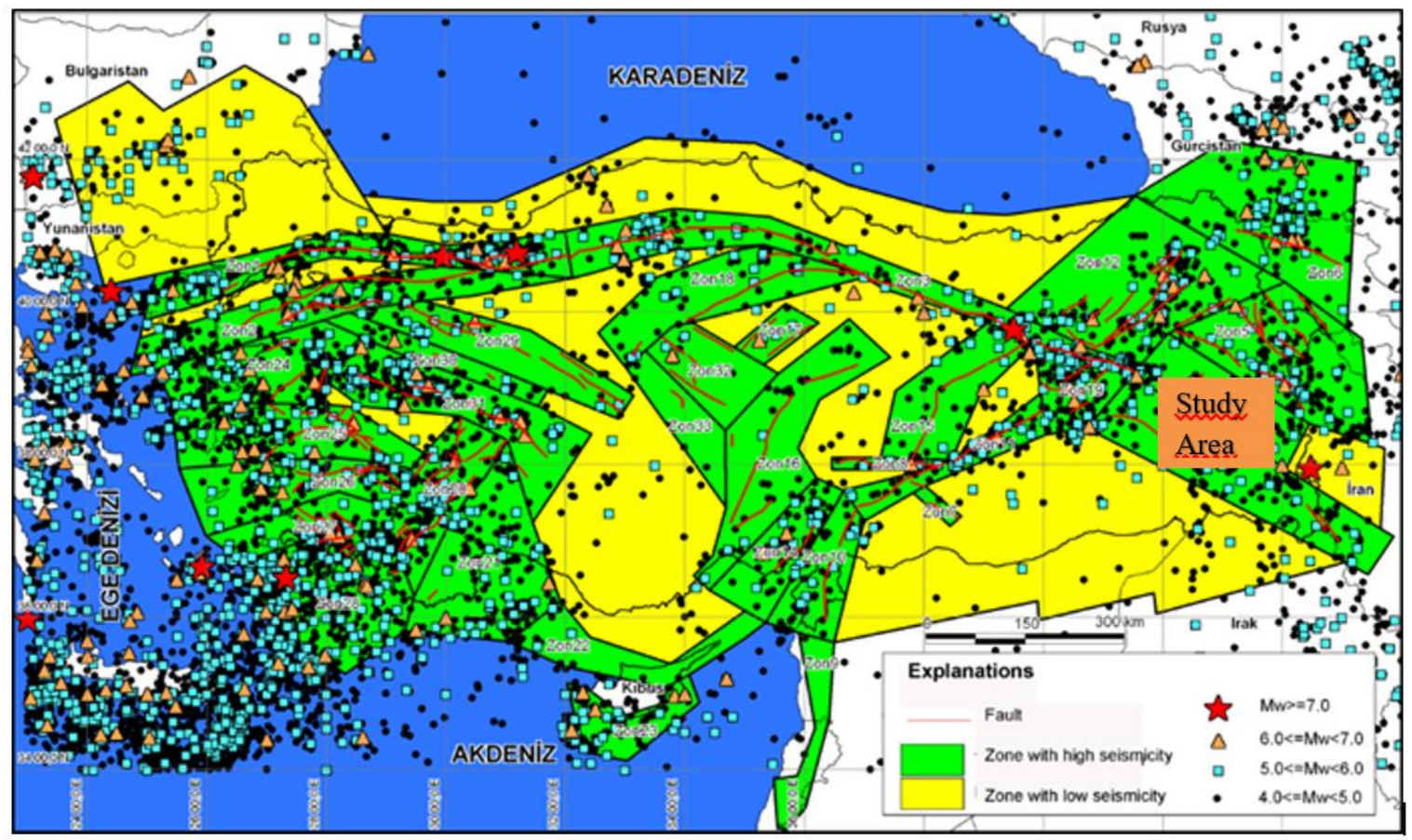

Fig. 2: Seismo-tectonics model of Turkey and the study area.

In Turkey, a new seismo-tectonic map was released to public by National Geological Survey [38]. ICOLD [3] defined the near-field motion, which is ground motion recorded in the vicinity of a fault. In this specification, a correlation between radius of near field area and earthquake magnitude is suggested as based on the cases on West United States. Authors established limits of near-field motion for the investigation area. According to this model, there are three dams, which are under the near-field motion. These dams can be subjected to earthquake having a magnitude (Mw) between 6.0 and 6.2 and the minimal distance to fault segment is between 3.0 and $29.6 \mathrm{~km}$, respectively. Three dams are not under near-field motion (Table 2).

Table 2: Results of deterministic and probabilistic analyses.

\begin{tabular}{|c|l|c|c|c|c|c|c|c|}
\hline \multirow{2}{*}{$\#$} & \multicolumn{1}{|c|}{ Dam } & $\mathrm{M}_{\max }$ & $\begin{array}{c}\mathrm{R}_{\text {min }} \\
(\mathrm{km})\end{array}$ & $\begin{array}{c}\text { Mean } \\
\text { PGA } \\
+50 \\
(\%)\end{array}$ & $\begin{array}{c}\text { Mean } \\
\text { PGA } \\
+84 \\
(\%)\end{array}$ & $\begin{array}{c}\text { OBE } \\
\text { in g }\end{array}$ & $\begin{array}{c}\text { MDE } \\
\text { in g }\end{array}$ & $\begin{array}{c}\text { SEE } \\
\text { in g }\end{array}$ \\
\hline 1 & Kockopru & 6.1 & 4.0 & 0.283 & 0.481 & 0.448 & 0.570 & 0.750 \\
\hline 2 & Morgedik & 6.1 & 3.0 & 0.304 & 0.515 & 0.513 & 0.649 & 0.884 \\
\hline 3 & Patnos & 6.1 & 22.8 & 0.101 & 0.172 & 0.185 & 0.234 & 0.302 \\
\hline 4 & Sarmehmet & 6.0 & 12.1 & 0.160 & 0.272 & 0.348 & 0.455 & 0.567 \\
\hline 5 & Sihke & 6.2 & 9.8 & 0.196 & 0.333 & 0.355 & 0.458 & 0.611 \\
\hline 6 & Zernek & 6.0 & 29.6 & 0.080 & 0.136 & 0.186 & 0.232 & 0.297 \\
\hline
\end{tabular}

(*) $\mathrm{M}_{\max }=$ Maximum earthquake magnitude in $\mathrm{M}_{\mathrm{w}}$

$\mathrm{R}_{\min }=$ Minimum distance to fault segment

Mean PGA $+50 \%=$ Mean Peak Ground Acceleration at the $50^{\text {th }}$ percentile

Mean PGA $+84 \%=$ Mean Peak Ground Acceleration at the $84^{\text {th }}$ percentile

(**) $\mathrm{OBE}=$ Operational Based Earthquake

MDE $=$ Maximum Design Earthquake

$\mathrm{SEE}=$ Safety Evaluation Earthquake 
The deterministic analyses indicate that peak ground acceleration (PGA) changes within an acceptable range when excluded three dams, which are under the near near-field motion. The PGA values ranges from $0.080 \mathrm{~g}$ to $0.304 \mathrm{~g}$ for the mean Peak Ground Acceleration at the $50^{\text {th }}$ percentile and from $0.136 \mathrm{~g}$ to $0.515 \mathrm{~g}$ for the mean Peak Ground Acceleration at the $84^{\text {th }}$ percentile given in table 2. However, the PGA values are high for the Kockopru and Morgedik dams. The probabilistic hazard analyses introduce PGA values within a wide range. The MDE values are between $0.232 \mathrm{~g}$ and $0.458 \mathrm{~g}$, while the OBE values ranges from $0.185 \mathrm{~g}$ to $0.355 \mathrm{~g}$, without considering two dams mentioned above.

\section{Total Risk Analysis}

The results related with total risk of the dams are given Table 3. One dam (Zernek) is classified into low hazard ratio with class I while three of them have moderate hazard rating with hazard class of II. Others are identified in class of IV with extremely high hazard rating. Two dam sites According to ICOLD (1989) classification, if the PGA value is greater than $0.25 \mathrm{~g}$ and the energy source is closer than $10 \mathrm{~km}$ from the dam site, it is classified as hazard class IV with hazard rating of extreme. For three dams, the distance from dam site to active faults, which are given on updated seismic maps, ranges from $3.0 \mathrm{~km}$ to $9.8 \mathrm{~km}$. The large dams of basins, which are under the influence of the near-field motion, have been constructed to very close to active segments of the normal fault system in East Anatolia.

According to DSI Guidelines all dams are categorized in II, III and IV risk classes with moderate, high and very high risk rating. Following Bureau's method, all large dams with exception of Kockopru and Sarımehmet dams are classified in risk class II with moderate-risk rating. The solution obtained from Bureau method is more rational than those estimated by the DSI guidelines.

Table 3: Total risk of dams considered for this study.

\begin{tabular}{|l|l|c|c|c|c|c|c|c|c|}
\hline \multirow{2}{*}{$\#$} & \multirow{2}{*}{ Dam } & \multicolumn{2}{|c|}{ Hazard Analysis } & \multicolumn{2}{|c|}{ Total Risk (ICOLD,1989) } & \multicolumn{3}{c|}{ Total Risk (Bureau, 2003) } \\
\cline { 3 - 10 } & Class & $\begin{array}{c}\text { Hazard } \\
\text { Ratio }\end{array}$ & $\begin{array}{c}\text { Risk } \\
\text { factor }\end{array}$ & $\begin{array}{c}\text { Risk } \\
\text { class }\end{array}$ & Risk ratio & $\begin{array}{c}\text { Risk } \\
\text { factor }\end{array}$ & $\begin{array}{c}\text { Risk } \\
\text { class }\end{array}$ & Risk ratio \\
\hline 1 & Kockopru, & IV & Very high & 34 & IV & Very high & 197.68 & III & High \\
\hline 2 & Morgedik, & IV & Very high & 30 & III & High & 120.18 & II & Moderate \\
\hline 3 & Patnos, & II & Moderate & 24 & III & High & 86.59 & II & Moderate \\
\hline 4 & Sarımehmet & II & Moderate & 36 & IV & Very high & 126.71 & III & High \\
\hline 5 & Sihke & II & Moderate & 16 & II & Moderate & 102.02 & II & Moderate \\
\hline 6 & Zernek & I & Low & 30 & III & High & 98.71 & II & Moderate \\
\hline
\end{tabular}

The values of the TRF range from 86.6 to 197.7 as based on Bureau method. This means that there is no dam having a risk class of I in the basin. There are four dams of a risk class of II and two dams of a risk class of III. In other words, thirty-three percent of total dams are identified approximately as a risk class of III, while the rest are identified as class of II.

\section{Results and Discussion}

In this study six large dams have been considered for their seismic hazard and total risk. Some of them, which are located on the main rivers of the basin and near metropolitan area, can cause very serious conditions for downstream life and property, when they fail. Therefore, their earthquake safety will be evaluated more detail as given below.

Kockopru dam is one of the main structures of the basin with volume of $2.0 \mathrm{hm}^{3}$ of earthfill type (Figure 4). Its construction was completed in 1992. Its height from river bed is $51.0 \mathrm{~m}$ [8]. When the reservoir is at operation stage with maximum water level, the facility approximately will impound $86 \mathrm{hm}^{3}$ of water with a reservoir surface area of $21.0 \mathrm{~km}^{2}$. The crest length is $700 \mathrm{~m}$ and the side slopes of main embankment is $3.0 \mathrm{H}: 1 \mathrm{~V}$ for upstream and $2.5 \mathrm{H}: 1 \mathrm{~V}$ for downstream $(\mathrm{H}=$ horizontal and $\mathrm{V}=\mathrm{vertical})$. On the section there is a central impervious core, which is composed of compacted clay and a transition section of sand was designed between the core and earthfill materials for both sides. The toe of 
downstream shells was supported by removed rock material. It is mainly designed to produce electricity with 8.5 MW of install capacity and to irrigate 9295 ha of land. The alluvium on river bed was removed before beginning the construction of the main embankment. The seismic hazard analyses performed throughout this study indicates that this dam is one of critical dams within the basin. It will be subjected to a peak ground acceleration of $0.283 \mathrm{~g}$ by an earthquake of 6.1 magnitude and it is only $4.0 \mathrm{~km}$ far away from an active fault. its risk is also high for downstream life.

Morgedik dam is a rockfill dam with a total embankment volume of $0.7 \mathrm{hm}^{3}$ Its height from river bed is $55.0 \mathrm{~m}$. Its construction was finished in 2014. When the reservoir is at operation stage with maximum water level, the facility approximately will impound $102.5 \mathrm{hm}^{3}$ of water. It was mainly designed to provide water for irrigation. The materials on river bed were removed before beginning the construction of the main embankment. The seismic hazard analyses performed throughout this study indicates that Morgedik dam is one of the critical dams within the basin. It will be subjected to a peak ground acceleration of $0.304 \mathrm{~g}$ by an earthquake of 6.1 magnitude and it is close to the fault segment $(3.0 \mathrm{~km})$.

The Patnos dam is a earthfill dam located near Patnos Province. It has a $32 \mathrm{~m}$ height from river bed. When the reservoir is at maximum capacity, the facility impounds $33.4 \mathrm{hm}^{3}$ of water. Its construction will be finished at the end of 1991. It was designed to irrigate lands in Patnos plain and also provide flood controlling. According to the seismic hazard analyses of this study, it will be subjected to a peak ground acceleration of $0.01 \mathrm{~g}$ by an earthquake of 6.1 magnitude. It is identified as class III with high risk according to ICOLD specification while it is categorized into class II with moderate risk $(\mathrm{TRF}=86.6)$. Dam site is located $22.8 \mathrm{~km}$ for away from an active fault.

The Sarımehmet dam is a earthfill dam on the Karasu River of Van Inner Basin. It has a 62.0-m height from foundation and the facility impounds $133.3 \mathrm{hm}^{3}$ of water with a reservoir surface area of $17.4 \mathrm{~km}^{2}$. when the reservoir is at maximum capacity. Its construction was finished in 1991. The crest length is $204.4 \mathrm{~m}$ and the side slopes of main embankment is $3.0 \mathrm{H}: 1 \mathrm{~V}$ for upstream and $2.5 \mathrm{H}: 1 \mathrm{~V}$ for downstream $(\mathrm{H}=$ horizontal and $\mathrm{V}=\mathrm{vertical})$ (Figure 5). On the section there is a central impervious core, which is composed of compacted clay and a transition section of sand was designed between the core and earthfill materials for both sides. It was designed mainly to irrigate land of 17700 ha. and also to produce electricity with an installed capacity of 3.5 MW. According to the seismic hazard analyses of this study, Sarımehmet dam is not a critical structure of Van Inner Basin that it will be subjected to a peak ground acceleration of $0.160 \mathrm{~g}$ by an earthquake of 6.1 magnitude. Dam site is located $12.2 \mathrm{~km}$ for away from an active fault.

The Sihke dam is a earthfill dam within the metropolitan area of Van city. Its construction was finished in 1957. It has a 11.2-m height from river bed and the facility impounds $9.2 \mathrm{hm}^{3}$ of water when the reservoir is at maximum capacity. Its system was mainly designed to provide water for local irrigation and recreation. According to the seismic hazard analyses of this study, it will be subjected to a peak ground acceleration of $0.196 \mathrm{~g}$ by an earthquake of 6.2 magnitude. Dam site is located $9.8 \mathrm{~km}$ for away from an active fault. Sihke dam is the oldest structure of the basin and has high total risk for downstream life. Its seismic stability should be upgraded soon.

Zernek dam is one of the main structures of the basin with volume of $2.1 \mathrm{hm}^{3}$ of earth-rockfill type. Its construction was completed in 1992. Its height from foundation is $80.0 \mathrm{~m}$ [8]. When the reservoir is at operation stage with maximum water level, the facility approximately will impound $105.8 \mathrm{hm}^{3}$ of water with a reservoir surface area of $20.4 \mathrm{~km}^{2}$. The crest length is $246 \mathrm{~m}$ and the side slopes of main embankment is $3.0 \mathrm{H}: 1 \mathrm{~V}$ for upstream and $2.5 \mathrm{H}: 1 \mathrm{~V}$ for downstream $(\mathrm{H}=$ horizontal and $\mathrm{V}=$ vertical) (Figure 9). On the section there is a central impervious core, which is composed of compacted clay and a transition section of sand was designed between the core and earthfill material for upstream shell and rockfill material for downstream shell. It is mainly designed to produce electricity with $4.5 \mathrm{MW}$ of install capacity and to irrigate 10300 ha of land. The alluvium on river bed was removed before beginning the construction of the main embankment. The seismic hazard analyses performed throughout this study indicates that this dam is not critical structure within the basin as based the current seismic data. It will be subjected to a peak ground acceleration of $0.080 \mathrm{~g}$ by an earthquake of 6.0 magnitude and it is $29.6 \mathrm{~km}$ far away from an active fault. its risk is at moderate level for downstream life. 
There are three dams are under the near-field motion when considered the new seismo-tectonic map of Turkey, introduced by MTA [38]. The analyses indicate that Kockopru and Sarimehmet dams are the most critical structures of the Van Inner Basin.

\section{Conclusion}

For this study, six large dams, which are located on different seismic zones of the Van Inner basin, were analyzed to estimate their seismic hazard and risk classes, as based on the actual earthquakes occurred within the basin and structural features of dams. As a result of this study, thirty-three percent of the dams under operation stage have been identified as the dams in very high hazard ratio, while fifty percent of dams are classified in moderate hazard ratio. There are three dams, which are under near-field motion in the basin. In other words, these dams are under the impact of near source zone. Especially Kockopru and Sarimehmet dams are the most critical structures of the Van Inner Basin. However, other large dams are relatively safe structures when we consider public safety. Author points out a fact that local predictive relationships or relationships, which were developed with considering similar seismo-tectonic environment, should be used to determine the seismic parameters to be used in dynamic analyses.

\section{References}

[1] ICOLD, "Selecting Parameters for Large Dams-Guidelines and Recommendations", ICOLD Committee on Seismic Aspects of Large Dams, Bulletin 72, 1989.

[2] G.J. Bureau, "Dams and Appurtenant Facilities in Earthquake Engineering Handbook" edited by Chenh, W.F and Scawthorn,C. CRS press, Bora Raton 26.1-26.47, 2003.

[3] ICOLD, Selecting Seismic Parameters for Large Dams-Guideline. ICOLD, Bulletin 148, 2016.

[4] H. Tosun. "Effects of the October 23, 2011 Van earthquake on dams" in Proceeding of ASSDO Annual Conference, 16-20 September 2012, Denver, Colorado.

[5] Bedirhanoğlu, I., Mollamahmutoğlu,C., İmamoğlu, M.S., (2018) "Damage of the Derbendikhan Dam during the Last Mw 7.3 Halabja Earthquake" Dam Safety 2019, pp. 27-31 October, Istanbul.

[6] DSİ. "Dams of Turkey" TR-COLD, Ankara, 602 p. 2016.

[7] E.Krinitzsky, "Discussion on Problems in the Application of the SSHAC Probability Method for Assessing Earthquake Hazards at Swiss nuclear power plants". Eng. Geol. 78, pp. 285-307; Eng.Geo. 82, pp. 62-68. 2005.J. P. Wilkinson, "Nonlinear resonant circuit devices," U.S. Patent 3624 125, July 16, 1990.

[8] S.L.Kramer, Geotechnical Earthquake Engineering. Prentice-Hall, Upper Saddle River, NJ 653 p, 1996.

[9] K.W. Campbell, "Near-Source Attenuation of Peak Horizontal Acceleration" Bulletin Seism. Soc. Am., V.71, N.6, pp.2039-2070, 1981.

[10] D.M.Boore, W.B. Joyner, and T.E.Fumal. "Estimation of response spectra and peak accelerations from Western North American earthquakes" An interim report. Open file report 93-509. U.S.G.S. 1993.

[11] N.N. Ambraseys. "The Prediction of Earthquake Peak Ground Acceleration in Europe" Earthquake Engineering and Structural Dynamics, V.24, pp. 467-490. 1995.

[12] K.W. Campbell and Y. Bozorgnia. "Near-source attenuation of peak horizontal acceleration from worldwide accelerograms recorded from 1957 to 1993" in Proceeding of the Fifth U.S. National Conference on Earthquake Engineering. V.3, pp. 283-292. 1994.

[13] D.M.Boore, W.B. Joyner, T.E.Fumal, "Equation for Estimating Horizontal Response Spectra and Peak Acceleration from Western North American Earthquakes”, A Summary of recent Work. Seismological Research Letters, V.68, N.1, January /February, pp. 128-153, 1997.

[14] P.Gulkan, E.Kalkan, "Attenuation modeling of recent earthquakes in Turkey”, Journal of Seismology, vol. 6, no. 3, pp. 397-409, 2002. 
[15] E.Kalkan, P.Gulkan, "Site-Dependent Spectra Derived from Ground Motion Records in Turkey", Earthquake Spectra, vol. 20, no. 4, pp. 1111-1138, 2004.

[16] N.N.Ambraseys, J.Douglas, S.K. Karma \& P.M.Smit, “Equations for the Estimation of Strong Ground Motions from Shallow Crustal Earthquakes Using Data from Europe and the Middle East- Horizontal Peak Ground Acceleration and Spectral Acceleration" Bulletin of Earthquake Engineering, 3, pp. 1-53, 2005.

[17] W.A.Fraser, J.K.Howard, Guidelines for Use of the Consequence-Hazard matrix and Selection of Ground Motion Parameters. Technical Publication, Department of Water Resources, Division of Safety of Dams, 2002.

[18] M.J.Jiminez, D.Giardini, G.Grünthal, "Unified Seismic Hazard Modelling throughout the Mediterranean Region”, Bolettino di Geofisica Teorica ed Applicata, Vol.42, N.1-2, Mar-Jun., pp. 3-18., 2001.

[19] FEMA, Federal Guidelines for Dam Safety_Earthquake Analyses and Design of Dams. 2005.

[20] H. Tosun, "Seismic studies", International Water Power \& Dam Construction, vol. 58, no. 2, pp. 20-23, 2006.

[21] H.Tosun, İ. Zorluer, A.Orhan, E.Seyrek, H.Savaş, M.Türköz, "Seismic hazard and total risk analyses for large dams in Euphrates basin, Turkey”, Engineering Geology 89 (1-2), pp. 155-170, 2007.

[22] H.Tosun, M.Turkoz, S.Savas, E.Seyrek, "River basin risk analysis”, International Water Power and Dam Construction, vol. 59, no. 5, p. 30, 2007.

[23] H. Tosun, "Evaluating Earthquake Safety for Large Dams in Southeast Turkey", Hydro Review Worldwide (HRW), pp. 34-40, 2008.

[24] H.Tosun, T.V.Tosun, Total risk and seismic hazard analyses of large dams in northwest Anatolia, Turkey. ICOLD $85^{\text {th }}$ Annual Meeting, July 3-7, Prague, 2017.

[25] H.Tosun, T.V.Tosun, M.A. Hariri-Ardebili, "Total risk and seismic hazard analysis of large embankment dams: case study of Northwest Anatolia, Turkey" Life Cycle Reliability and Safety Engineering, 1-10, 2020 (https://doi.org/10.1007/s41872-020-00113-4).

[26] H. Tosun, "Earthquakes and dams" in charter of Earthquake Engineering (edited by A.Moustafa), Chapter 7, Intechopen, pp. 189-198, 2015, http://dx.doi.org/10.5772/59372

[27] H.Tosun, E.Seyrek, "Total risk analyses for large dams in Kizilirmak basin, Turkey", Natural Hazards and Earth System Sciences, vol. 10, no. 5, p. 979, 2010.

[28] E.Seyrek, H.Tosun, "Deterministic approach to the seismic hazard of dam sites in Kiz1lırmak basin, Turkey" Natural hazards, vol. 59, no. 2, p. 787, 2011.

[29] E.Seyrek, H.Tosun, "Influence of analysis methods for seismic hazard on total risk of large concrete dams in Turkey", Gazi Univ, J.Fac Engineering Architecture, 28-1, pp. 67-75, 2013.

[30] H Tosun, T.V Tosun "Dynamic Analysis of Embankment Dams Under Strong Seismic Excitation and a Case Study", in Proceeding of Long-Term Behaviour and Environmentally Friendly Rehabilitation Technologies of Dams (LTBD 2017), Tehran, 2017, DOI:10.3217/978-3-85125-564-5-102.

[31] H.Tosun, "Seismic Stability of Large Dams Located Near Energy Source And A Case Study" in Proceeding of 5th International Conference on Earthquake Engineering and Seismology, METU-Ankara 8-11 October 2019.

[32] H.Tosun, "Earthquake Safety Evaluation for Large Dams Located near the Energy Source and Case Studies", in Proceeding of 11th ICOLD Europen Clup Symposium, Chania, Crete, 2-4 October 2019.

[33] H.Tosun, "Earthquakes and Dams", in Earthquake Engineering - From Engineering Seismology to Optimal Seismic Design of Engineering Structures, edited by Abbas Moustafa, IntechOpen, May 2015, (DOI: 10.5772/59372).

[34] H.Tosun, M.Turkoz, H.Savas and E.Igdirsel "Deformation and stress analysis of concrete-faced rockfill dam by finite element method and a case study" Seminar on Dam and Earthquake, May 11-12, Eskisehir Osmangazi University, 2006 (in Turkish).

[35] H.Tosun and R.Ulusay. "Engineering Geological Characterization and Evaluation of Liquefaction Susceptibility of Foundation Soils at a Dam Site, Southwest Turkey" Environmental and Engineering Geoscience, III (3): pp. 389-409, 1997. 
[36] H.Tosun, T.Mirata, M.Mollamahmutoglu, and N.S.Colakoglu, " Shear strength of gravel and rockfill measured in triaxial and prismatic wedge shear tests" Electronic Journal of Geotechnical Engineering, EJGE Paper 9903, 1999

[37] DSİ, Selection of Seismic Parameters for Dam Design, State Hydraulic Works. Ankara, 29 p, 2012 (in Turkish).

[38] General Directorate Of Mineral Research And Explorations (MTA), Geoscience Map Viewer and Drawing Editor, http://yerbilimleri.mta.gov.tr/ 